The following Paper received the Second Place, Under the category of Over 35 years of age at the "Water Related Infrastructure" Competition" 2004/2005, Sponsored by the St. Anthony's Industries Group (Pvt) Ltd.

\title{
Optimization of Hydro-Power Potential of Samanalawewa Project
}

\author{
D.D. Wijesinghe
}

\section{Introduction}

The Ceylon Electricity Board under the Ministry of Power \& Energy commenced the construction of Samanalawewa Hydroelectric Project in early 1987. The aim of the project was to harness the hydro electric potential of the Walawe Ganga to produce about 430 million units of firm electrical energy per anum and to add $120 \mathrm{MW}$ power to the national grid. The project consists of a rockfill dam with a crest length of about $530 \mathrm{~m}$ and a height of about $100 \mathrm{~m}$ above the river bed level. Samanalawewa dam is located just downstream of the confluence point of Walawe Ganga and Belihul Oya , one of its main tributaries. The reservoir created by the dam has a total live storage capacity of $218 \mathrm{MCM}$ and the dead storage is about $60 \mathrm{MCM}$. The $U$ shaped reservoir spreads to a distance of $8 \mathrm{~km}$ upstream along two limbs of the Walawe Ganga and Belihul Oya. The intake with the waterway system for the powerhouse is located about $6 \mathrm{~km}$ upstream of the dam. At this region, the reservoir and a secondary tributary of Walawe, Katupath Oya come nearest to each other and the level difference exceeds $400 \mathrm{~m}$. (Fig 1)

The principal feature of the project is to make use of this difference for power generation at a power station on the left bank of Katupath Oya . The plant has been generating power since its commissioning in October 1992, amidst the leakage problem which developed in the reservoir due to the adverse geological conditions prevailing in the Right Bank. The reservoir was operated $30 \mathrm{~m}$ below the full supply level until reservoir remedial works were completed in 1999. The reservoir remedial works - Wet Blanketing was successfully completed by lowering ground water level of the right bank ridge to a safe limit even at the full supply level. However, the reduction of main leakage was only $25 \%$ and it stands maximum of 2.18 cumecs at full supply level of $460 \mathrm{~m} \mathrm{MSL}$. It fluctuates with the reservoir level and recorded minimum value was 1.37 cumecs at $428 \mathrm{~m}$ MSL

Ceylon Electricity Board (CEB) has obligations to release sufficient water from the Samanalawewa Dam for downstream water users, which was, estimated about $80 \mathrm{MCM}$ annually. Since the average runoff of the reservoir is $590 \mathrm{MCM}$, downstream release significantly affect the total energy production of the project.

CEB continues to loose about $28 \mathrm{GWH}$ annually due to additional irrigation release from the reservoir as this water does not pass through turbines. This paper propose to establish a system of mini-hydro power plants to recapture the lost energy and to enhance the power potential from the project.

\subsection{Downstream water releases}

The dam has been provided Irrigation and low level outlets to release irrigation requirements of the downstream and emptying in case of emergency. This is by means of a $2 \mathrm{~m}$ diameter steel pipeline extending up to the downstream face of the dam and installed in one of the diversion tunnels (Tunnel 1). At the downstream end of the pipeline a hydraulically driven Jet flow gate with a maximum discharge capacity of 70 cumecs at full supply level is provided for discharge regulation. Irrigation release is facilitated through a small by pass line fitted with a Howell Bunger valve and it has max discharging capacity of 7 cumecs at full supply level.
The diverted water for power generation reenters the Walawe Ganga about $20 \mathrm{~km}$ downstream of the dam.

The Kaltota Irrigation Scheme that was completed in early 60's is situated $12 \mathrm{kms}$ downstream of the Samanalawewa Dam. It has a command area of $1100 \mathrm{Ha}$ and water is supplied to the scheme from the Uggal Kaltota anicuts in the Walawe Ganga. The two anicuts divert water to both the Left Bank Canal and the Right Bank Canal. Since

Eng. D D. Wjesinghe, BSc Eng., M.TectalTO), C.Eng., MIE(SW)

Conruling Engineer, Nppon Koel Ca, Uad 
the construction of Samanalawewa Reservoir, the Uggal-kaltota anicut receives water from a reduced catchment area of $68.0 \mathrm{sq} . \mathrm{kms}$ below the Samanalawewa dam due to interception of 342 sq. $\mathrm{kms}$ by the dam.

Since the riparian rights of the downstream water users have to be respected, CEB has to issue sufficient quantities of water for irrigation. The average water release from Samanalawewa Dam to the Kaltota irrigation scheme is more than $\mathbf{3 . 0}$ cumecs in most of the year. An average flow of 1.62 cumecs is received from natural release of the main leak in the Right Bank of the dam and the balance through the irrigation outlet of the dam. Table 1 shows the annual discharge from the Samanalawewa Reservoir to the downstream from 1993 to 2004. The annual average runoff of the Samanalawewa reservoir is estimated as 598 MCM and average downstream release amount to $91 \mathrm{MCM}$ for the period of 1999 to 2004.

\section{Downstream water requirements.}

A continuous downstream release is essential at the Samanalawewa dam for the irrigation requirement and environmental requirement.

\subsection{Irrigation requirement}

Theoretically, natural leakage is sufficient for irrigation requirements in most of the year except during land preparation. However, additional releases through Irrigation Outlet are required due to reach losses and excessive water duty of Kaltota Scheme.

It is established that nearly 4000 farmer families are engaged in Paddy and other crop cultivation. - Details of the present extent of the irrigated lands are as follows.

Command area of the Right Bank Canal
1. Puranagama $256 \mathrm{Ha} \quad$ (633 Acres)
2. Welipothayaya $289 \mathrm{Ha}$ (714 Acres)
3. Pahathbima $61 \mathrm{Ha}$ (150 Acres)
Sub Total $\quad 606 \mathrm{Ha} \quad$ (1497 Acres)

Command area of the Left Bank Canal

$\begin{array}{lll}\text { 4. Medabedda } & 309 \mathrm{Ha} & \text { (763 Acres) } \\ \text { Sub Total } & 309 \mathrm{Ha} & \text { (763 Acres) } \\ \text { Total } & 915 \mathrm{Ha} & \text { (2260 Acres) }\end{array}$

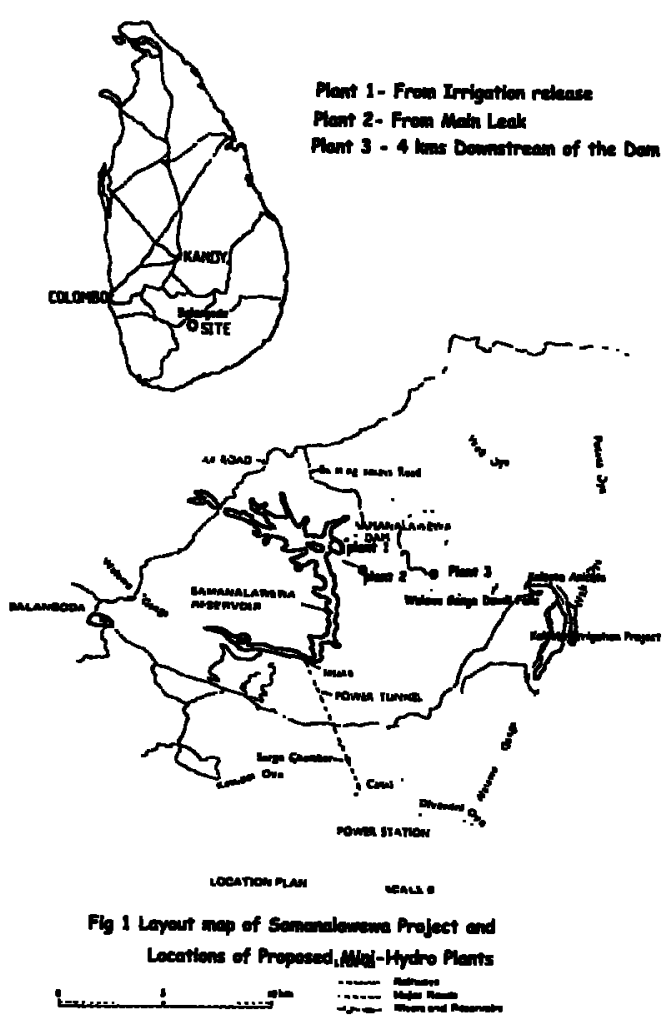


In view of the increasing demand for irrigation water at the Kaltota Irrigation Scheme arising out of the pressure to develop agricultural land to cope with an increasing population, it is very unlikely that there would be a decrease in the release of water from the Samanalawewa Dam in the near future. Further construction of the Samanalawewa Dam has effectively reduced the risk of flood in the flood plain of the Walawe River in the Kaltota scheme. This enables encroachment and utilization of the flood plain for human activities resulting increasing demand for irrigation water well above the designed capacity. Placed in such a situation the release of water from the Samanalawewa Dam has to be maintained at least at the present level continuously.

\subsection{Environmental requirement}

At the time of construction of Samanalawewa dam, there was no strict environmental regulations imposed on major development works. Therefore environmentalist attention was not drawn for the cut-off of river flow to the Duvili Falls located downstream of dam. But today, the location has developed as major local tourist attraction in the area. In any event it would be necessary to release about 1.5 cumecs to sustain the beauty of waterfall.

\section{Loss of power potential due to controlled release}

The water released from Samanalawewa dam has a very high "Opportunity cost" attached since the option of generating power out of this has to be forgone. As there is no control for natural leakage, value can be attached only for Irrigation outlet releases.

Table 2 gives the average energy storage of one cubic metre of the reservoir for different reservoir levels. The operating head of turbines of the Samanalawewa power station is more than $300 \mathrm{~m}$ and therefore, reservoir level fluctuation has little impact on energy storage per cubic metre in the reservoir.

The amount of lost energy can be calculated using daily monitoring data of the water release and reservoir level. Table 3 shows the loss of energy from 1999 to 2004.

The average loss of electrical energy for the last six years of operation is $28 \mathrm{GWH}$ and the value could be estimated as RS $\mathbf{2 0 0}$ million at current average selling price of electricity unit.

Table 1:

Annual discharges from Natural Main Leak and Irrigation Outlet

\begin{tabular}{|c|c|c|c|}
\hline Year & $\begin{array}{c}\text { Annual Discharge from } \\
\text { the Main Leak }\end{array}$ & $\begin{array}{c}\text { Annual Discharge from } \\
\text { the Irrigation Outlet }\end{array}$ & $\begin{array}{c}\text { Total Discharge to the } \\
\text { Downstream }\end{array}$ \\
\cline { 2 - 4 } & MCM & MCM & MCM \\
\hline 1993 & 62.88 & 26.83 & 89.71 \\
1994 & 69.42 & 37.44 & 106.86 \\
1995 & 67.97 & 26.55 & 94.52 \\
1996 & 67.39 & 16.10 & 83.49 \\
1997 & 74.00 & 5.60 & 80.50 \\
1998 & 65.00 & 11.70 & 77.60 \\
1999 & 62.10 & 29.00 & 91.10 \\
2000 & 52.60 & 44.30 & 97.10 \\
2001 & 52.40 & 41.30 & 93.70 \\
2002 & 48.90 & 37.80 & 86.70 \\
2003 & 56.23 & 29.50 & 85.73 \\
2004 & 53.40 & 38.90 & 92.30 \\
\hline
\end{tabular}


Table 2:

Energy and water storage at different levels of Samanalawewa Reservoir

\begin{tabular}{|c|c|c|c|}
\hline $\begin{array}{c}\text { Reservoir } \\
\text { Level MSL } \\
(\mathbf{m})\end{array}$ & $\begin{array}{c}\text { Live storage } \\
\text { (MCM) }\end{array}$ & $\begin{array}{c}\text { Energy storage at this } \\
\text { level (GWh) }\end{array}$ & $\begin{array}{c}\text { Energy Storage (kWh) } \\
\text { per cubic metre of water } \\
\text { in the reservoir }\end{array}$ \\
\hline 425 & 0 & 0 & 0.7537 \\
430 & 21.123 & 16.049 & 0.7598 \\
435 & 43.543 & 33.351 & 0.7659 \\
440 & 69.077 & 53.332 & 0.7721 \\
445 & 97.639 & 75.982 & 0.7732 \\
450 & 129.914 & 101.983 & 0.7843 \\
455 & 168.274 & 133.011 & 0.7904 \\
460 & 218.064 & 173.703 & 0.7966 \\
\hline
\end{tabular}

\section{Method of Recovery of Lost Energy}

Reduction of consumption of water for irrigation is one of the options for minimizing the loss of power generation. It is reported that various methods of farming practice such as staggering of land preparation, rotational distribution of water, alternative crops introduction and use of "Madagaskar Method" a method using less water for paddy cultivation have been tried out without much success.

Therefore, it is proposed to operate mini hydropower plants using irrigation water to recover energy as much as possible. Three potential sites have been identified. They are

1. Mini hydro power plant at Irrigation outlet

2. Mini hydro power plant using main leakage water and

3. Mini hydro power plant $4 \mathrm{kms}$ downstream of the dam

Locations of the proposed plants are.shown in Fig 1.

The objectives will be

1. To optimize the power benefits from the Samanalawewa project as originally designed after achieving the reservoir storage function by Reservoir Remedial works - Wet Blanketing.

2. Harness renewable energy and thereby contributing to national development by introducing environmental friendly "indigenous" power source.
3. To reduce the need for thermal power plants thereby minimizing the air pollution.

The water releases to the downstream from the Samanalawewa Dam could be utilized to generate about 28 GWH of electricity energy annually from three mini-hydro plants with combined installed capacity of $5.6 \mathrm{MW}$ and water shall be released back to the Walawe River for irrigation.

\subsection{Mini-Hydro plant Utilizing Irrigation Release}

Samanalawewa dam has an irrigation and bottom outlet installed in one of the diversion tunnel. The steel conduit has a guard valve (butterfly valve) towards the reservoir side and a bifurcation for two gated outlets at the downstream end. The bottom out let can release maximum 70 cumecs and the irrigation valve can discharge maximum about 7 cumecs. It has been observed that the bottom outlet has to keep open $70 \%$ of the time to supplement downstream irrigation requirement. It is proposed to tap the steel conduit before the bifurcation to facilitate an inlet for the proposed mini-hydro plant. This plant can be located inside the diversion tunnel in a $3 \mathrm{~m}$ wide passage adjacent to the bifurcation block.

\subsubsection{Flow Characteristics \& Design Flow}

Outflow data from the irrigation valve on daily basis is available since impounding in May1991. The main leak appeared in October 1992 and the reservoir remedial works completed towards the beginning of 1999. Since then, a regular pattern of water releases can be observed. Therefore, for the purpose of this study, flow records from 1999 to 2003 were considered. 
Table 3 :

Loss of Power generation due to Controlled

Release for Irrigation

\begin{tabular}{|c|c|c|}
\hline Year & $\begin{array}{c}\text { Irrigation Release } \\
\text { (MCM) }\end{array}$ & $\begin{array}{c}\text { Loss of power generation due } \\
\text { to Irrigation release (GWH) }\end{array}$ \\
\hline 1999 & 29.00 & 21.939 \\
2000 & 44.30 & 33.936 \\
2001 & 41.30 & 31.670 \\
2002 & 37.80 & 27.160 \\
2003 & 29.50 & 22.857 \\
2004 & 38.90 & 29.899 \\
\hline Average & & 27.910 \\
\hline
\end{tabular}

The associated hydrograph of the plant is shown in the Fig. 2 based on daily flow records. The minimum and the maximum discharges are 0.5 cumecs and 3.0 cumecs respectively. The flow duration curve is given in the Fig 3 .

In view of the increasing demand for irrigation water at the Kaltota Irrigation Scheme, it is sensible to design the plant for 3.0 cumecs.

\subsubsection{Gross Head of the Irrigation Outlet Power Plant}

The minimum operation level and the full supply level of the Samanalawewa reservoir are $424 \mathrm{~m}$ $\mathrm{msl}$ and $460 \mathrm{~m} \mathrm{msl}$. respectively. The tailrace level of the plant shall be $365.5 \mathrm{~m} \mathrm{msl}$ Accordingly, the available head for the plant varies between 94.5 $\mathrm{m}$ and $60.5 \mathrm{~m}$. However, in most of the time the reservoir operates between $430 \mathrm{~m}$ to $455 \mathrm{~m}$ msl.
Therefore, for the purpose of design of the plant, the maximum head available was taken as $90 \mathrm{~m}$.

\subsubsection{Power Plant}

The turbine with the spiral casing and draft tube shall be installed on the invert of the diversion tunnel adjacent to the bifurcation block The invert level of the diversion tunnels is $365 \mathrm{~m} \mathrm{msl}$. An opening shall be provided for the draft tube by breaking concrete wall, downstream face of the tunnel. The plunge pool water level is about $365 \mathrm{~m}$ $\mathrm{msl}$. This level can be taken as the tailrace level.

It is recommended to install Tergo Impulse or Francis type, vertical axis, and medium speed turbine. However, a detailed study shall be carried out to select the most suitable type of turbine considering the head variation and flow variation during the detailed design stage. The installed capacity of the plant is estimated about $2.0 \mathrm{MW}$.

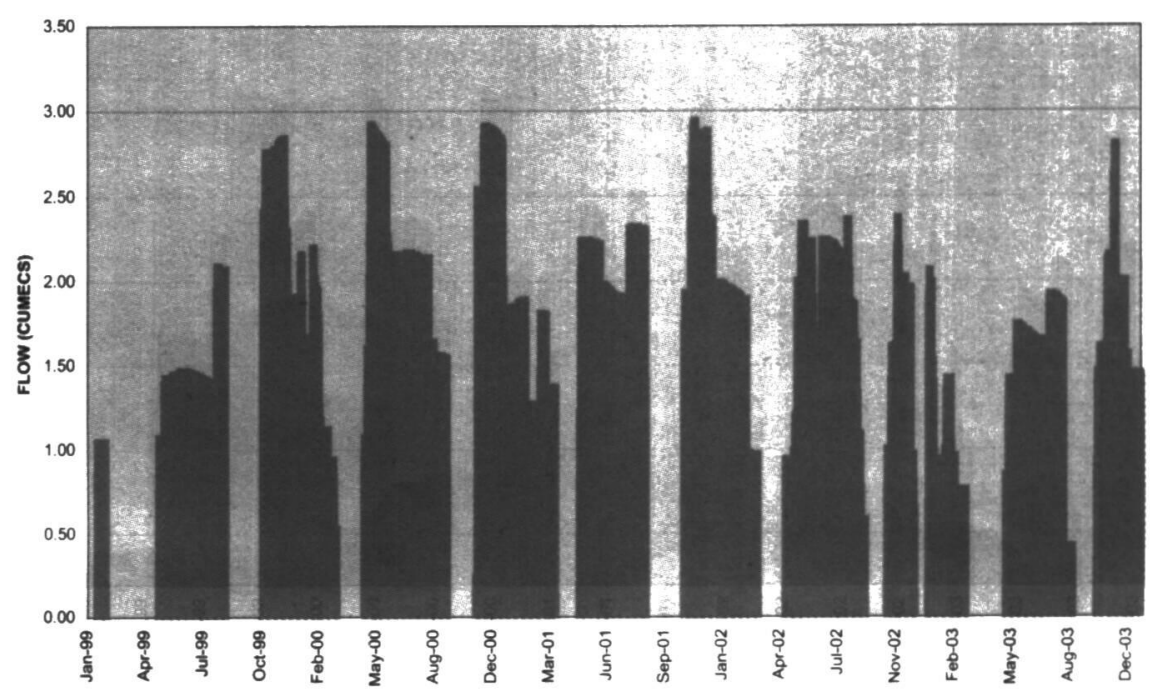

Figure 2 : Hydrograph for Daily Irrigation Release 


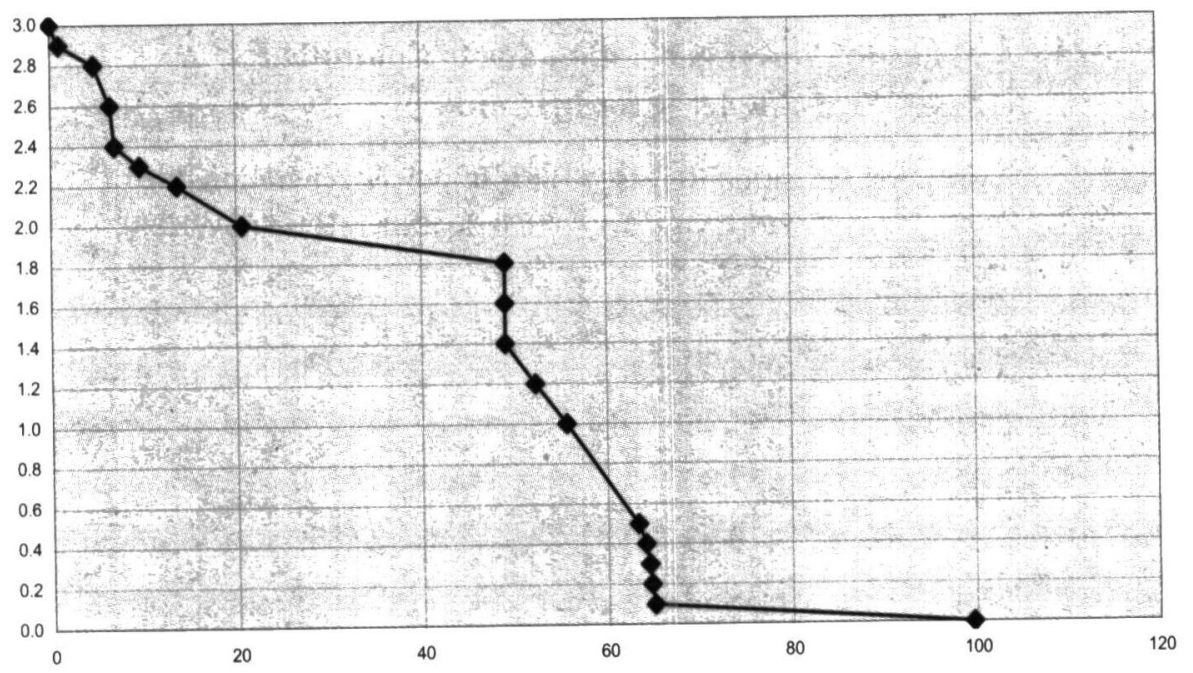

Figure 3 : Flow Duration Curve - Irrigation Release

4.1.4 Annual Energy benefits of the Irrigation Power Plant

$\begin{array}{ll}\text { Design Flow } & =3.0 \text { Cumecs } \\ \text { Net design head } & =90 \text { meters } \\ \text { Turbine Efficiency } & =0.90 \\ \text { Installed Capacity } & =2,000 \mathrm{~kW} \\ \text { Plant factor } & =0.36 \\ \text { Annual Energy } & =6.2 \mathrm{GWh} \\ \text { Annual Income } & =\text { Rs. } 36 \text { Million }\end{array}$

Simulation studies for the proposed power plant operation under varying hydrological conditions were carried out using the actual reservoir head and daily flow readings for the past six years.. Annual Energy Potential based on actual flow data is given in Table 4.

\subsection{Mini-hydro plant Utilizing Main leakage}

Before the conclusion of the reservoir remedial works - wet blanketing, the maximum leakage at full supply level was 2.7 cumecs. This was reduced to 2.2 cumecs in December 1998 after wet blanketing. Therefore, the flow measurements before 1999 was discarded, as they were no longer represent the actual present conditions.

Table 4 :

Annual Energy Potential of Proposed Mini-Hydro Plants and comparison of Annual Energy Production with Samanalawewa Power Station (Unit; GWh)

\begin{tabular}{|c|c|c|c|c|c|}
\hline \multirow{2}{*}{ Year } & \multicolumn{4}{|c|}{ Mini Hydro Power Plants } & \multirow{2}{*}{$\begin{array}{c}\text { Samanalawewa } \\
\text { Power Station }\end{array}$} \\
\hline & Irrigation Outlet & Main Leak & $\begin{array}{c}\text { Four kms } \\
\text { Downstream }\end{array}$ & Total & \\
\hline 1999 & 5.431 & 6.436 & 15.504 & 27.371 & 320.393 \\
\hline 2000 & 7.454 & 5.477 & 16.864 & 29.795 & 284.756 \\
\hline 2001 & .7 .029 & 5.445 & 16.576 & 29.050 & 210.422 \\
\hline 2002 & 6.035 & 5.127 & 16.114 & 27.276 & 187.348 \\
\hline 2003 & 5.280 & 5.883 & 15.339 & 26.502 & 320.050 \\
\hline 2004 & 6.864 & 5.540 & 17.133 & 29.537 & 233.800 \\
\hline Avg. & 6.349 & 5.643 & 16.255 & 28.247 & 259.237 \\
\hline
\end{tabular}

Percentage of Annual Energy from Mini Hydro Plants to that of Samanalawewa Power Station for the last 6 years $=(28.247 / 259.237)$

$$
=11 \%
$$


The main leakage found to be stable and it fluctuates with the reservoir level. Leakage emerges from the right bank ridge at about elevation 393 m MSL.

\subsubsection{Flow Characteristics \& the Design Flow of the Main Leak}

The associated hydrographs of the plant are shown in the Fig. 4 based on daily flow measurements. The mean average flow of the leak is 1.74 cumecs. The minimum and the maximum flow are 1.34 cumecs and 2.2 cumecs respectively.

The flow - duration curve is given in the Fig 5 . The design flow is taken as 2.0 cumecs.

\subsubsection{Intake and the Headrace Canal}

The intake water level at the leakage outlet is $293 \mathrm{~m} \mathrm{msl}$. The intake shall be located just downstream of the outlet. It is proposed to transmit the leakage flow along a contour canal. On the Right Bank. The total length of the canal shall be 700 meters. The design capacity of the canal would be 2.20 cumecs with a velocity of the flow of $1.8 \mathrm{~m} / \mathrm{s}$. The entire length of the canal shall be lined to avoid any seepage and transmission losses The slope of the canal shall be 0.001 in order to reduce the sectional area as the canal is running along a steep slope for a distance of $200 \mathrm{~m}$. Aqueducts shall be provided in most of the places. However, the construction will not be difficult due to convenient access along the canal route.
A rectangular section $(1.80 \mathrm{~m} \mathrm{X} 1.20 \mathrm{~m})$ will be selected with $0.3 \mathrm{~m}$ freeboard

A measuring weir or flume shall be incorporated to the intake structure to continue monitoring of main leak.

\subsubsection{Forebay Tank and Spill}

A forebay tank with a large stilling tank and a trash rack shall be provided at the end of the headrace canal. A side spill shall be incorporated to the forebay tank in order to release the flow during emergency shut off of the machine.

\subsubsection{Power House, Penstock and Tailrace}

The powerhouse shall be located on the right bank of the Walawe Ganga close to the confluence of Kalunaide Ara with the river at an elevation 350 $m$ MSL. The tailrace canal would be provided and the design water level of tailrace would be $246 \mathrm{~m}$ MSL. The estimated length of the penstock is 200 meters.

The Samanalawewa spillway, which was designed for a flood with the return period of 1000 years, has the flood discharge capacity of 3600 cumecs. Due consideration will be given to the possibility of flood waters wash away the plant in a rare event of a 1000 year flood. A detailed analysis should be carried out to select the exact location and the machine chamber elevation of the powerhouse.

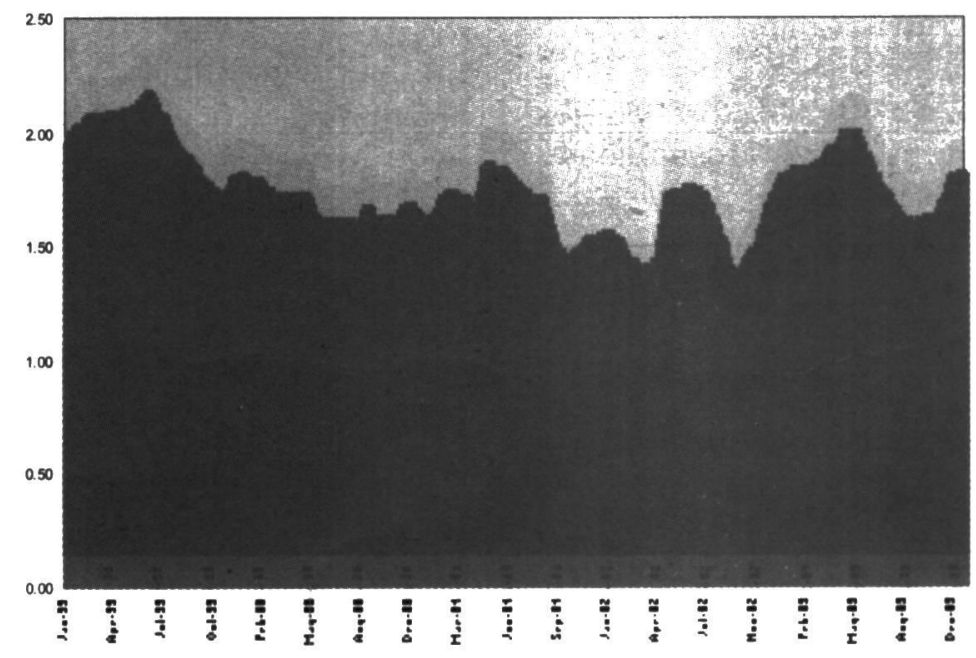

Figure 4 : Daily Canal Flow at the Gauging Site (Main Leak) 


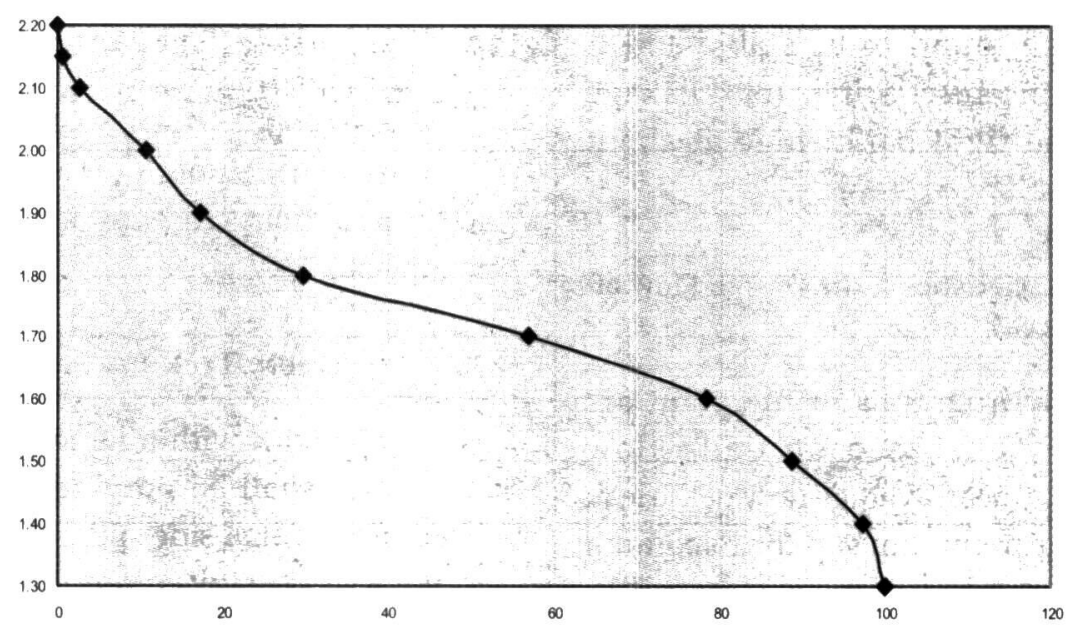

Figure : 5 Flow-Duration Curve, Main Leak

\subsubsection{Turbines and Generators}

It is suggested that 1 unit of $800 \mathrm{~kW}$, medium speed Francis turbine shall be installed. Selection of best type of turbine and the number of units shall be determined after a detailed study of the project components

\subsubsection{Power and Energy Benefits}

It is estimated that the total head loss from the canal and structures is in the range of $2.7 \mathrm{~m}$. The available head for power generation is 42 meters.

$\begin{array}{ll}\text { Design Flow } & =2.1 \text { Cumecs } \\ \text { Net head } & =42 \text { meters } \\ \text { Turbine Efficiency } & =0.90 \\ \text { Installed Capacity } & =800 \mathrm{~kW} \\ \text { Plant factor } & =0.83 \\ \text { Annual Energy } & =5.7 \mathrm{GWh} \\ \text { Annual Income } & =\text { Rs. } 33 \text { Million }\end{array}$

Simulation studies for the proposed powerhouse operation under varying hydrological conditions were carried out using the actual daily flow readings for the past six years. Annual Energy Potential based on flow data from 1999 to 2004 is given in Table 4.

\subsection{Mini hydro plant $4 \mathrm{kms}$ downstream of the dam}

Between Samanalawewa Dam and Kaltota Escarpment the Walawe Ganga flows eastwards along a tortuous, steep sided valley that crosses the predominant geological structure of the Balangoda syncline. The river forms sequences of mini waterfalls cascades in this section. A suitable site has been identified $4 \mathrm{kms}$ downstream of the dam where river drops about $70 \mathrm{~m}$ within $2 \mathrm{kms}$ length of the river. A diversion weir has to be constructed downstream of the confluence of Walawe Ganga and Dewagalle Ara, a tributary of it to divert river flow. The headrace canal, 1600 metres in length, would be located on the left bank of the river.

\subsubsection{Hydrology}

The river flow measurements have to be modified to include the Dewagalle Ara stream flow and Baduludena Ara which are estimated, very conservatively, as 0.25 cumecs and 0.10 cumecs respectively.

Dewagulu Ara has a firm flow of 0.25 cumecs due to a series of springs that appeared along its bank and Kille Kandura Ara, which is a tributary of it, after impounding the Samanalawewa reservoir.

Catchment of Baduludena Ara is only $4 \mathrm{sq} . \mathrm{kms}$ and the natural flow was estimated using specific yield of Weli Oya catchment and long term rainfall distribution of the area.

\subsubsection{Design Flow (Qd)}

The Optimum value for the design flow is found to be 5.0 cumecs. The $80 \%$ of the design flow would be available $47 \%$ of the time and $50 \%$ of the design flow would be available for $84 \%$ of the time. The flow - duration curve associated with the hydrograph (Fig 6) is given in Fig. 7. 




Figure 6 : Hydrograph for the Gauging Site



Figure 7 : Flow Duration Curve



Main Leakage Outlet

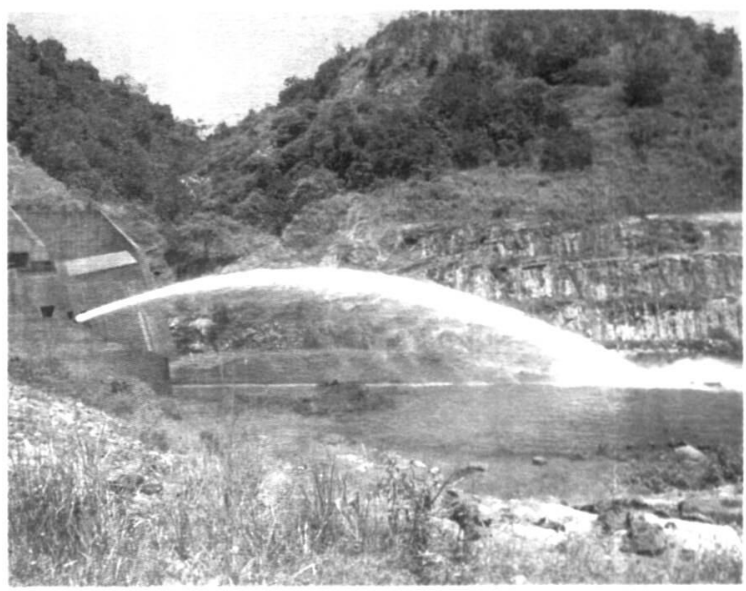

Water Release Through Irrigation Outlet 


\subsection{3}

Natural formation of the river with a small builtup weir is found to be adequate to divert the river flow to the Power canal. The intake shall be located downstream of the confluence of Dewagulu Ara and the Walawe Ganga. The coordinates of the location are $\mathrm{N} 163,700 \mathrm{~m}$ and $\mathrm{E}$ $204,600 \mathrm{~m}$. River bed level at the barrage is about $318 \mathrm{~m}$ MSL and the design water level at the intake is $320 \mathrm{~m}$ MSL. A continuous release of 0.100 cumecs shall be allowed permanently to satisfy . environmental regulation. Two gated low level outlets shall be provided in the weir. The spill length of the weir is $35 \mathrm{~m}$.

In the rainy season, the irrigation release from the Samanalawewa is reduced. Therefore diversion of Baduludena Ara to the fore bay in rainy period has significant impact on the total annual energy produced from the plant.

\subsubsection{Head Race Canal}

The head race canal shall be located on the Left Bank of the river. It would be a $1600 \mathrm{~m}$ long contour canal.

Design parameters of the Headrace Canal

$\begin{array}{ll}\text { Design Flow } & -5 \text { Cumecs } \\ \text { Slope of the Canal (s) } & -0.0015 \\ \text { Assumed friction coefficient }(\mathrm{n}) & -0.015 \\ \text { Velocity of the flow } & -1.8 \mathrm{~m} / \mathrm{s} \\ \text { Width of the Canal } & -2.2 \mathrm{~m}\end{array}$

Depth of the Flow at Maximum flow-1.256 m

Freeboard $\quad-0.30 \mathrm{~m}$

\subsubsection{Forebay}

A forebay with a large stilling tank $(6 \mathrm{~m} \times 20 \mathrm{~m})$ and a trash rack shall be provided at the end of canal.. A side spill shall be incorporated to the stilling tank and the spillway canal shall be constructed up to Baduludena Ara with adequate energy dissipaters.

\subsubsection{Penstock and Powerhouse}

A surface penstock line shall be constructed. The total length of the penstock line would be $550 \mathrm{~m}$. Nine anchor blocks and 56 nos ring supports shall be provided for the penstock. Bifurcation shall be located close to the powerhouse. Diameter of the penstock line would be $1.35 \mathrm{~m}$
The powerhouse shall be located on the left bank of the Walawe Ganga close to the confluence of Baduludena Oya with the river at an elevation $253 \mathrm{~m}$ MSL. The tailrace canal would be provided and the design water level of tailrace would be $250 \mathrm{~m}$ MSL.

\subsection{Power \& Energy Benefits}

$\begin{array}{ll}\text { Intake water level } & 320 \mathrm{~m} \text { MSL } \\ \text { Canal length } & 1600 \mathrm{~m} \\ \text { Forebay Level } & 317.6 \mathrm{~m} \text { MSL } \\ \text { Penstock losses } & 4.3 \mathrm{~m} \\ \text { Tailrace level } & 249.8 \mathrm{~m} \text { MSL } \\ \text { Net head } & 63.5 \mathrm{~m} \\ \text { Design Flow } & 5 \text { cumecs } \\ \text { Turbine/Gen. Efficiency } & 0.90 \\ \text { Installed Capacity } & 2800 \mathrm{~kW} \\ \text { Annual Energy } & 16.47 \mathrm{GWH} \\ \text { Annual Income } & \text { Rs. } 92 \mathrm{Million}\end{array}$

\section{Connection to the National Grid}

$33 \mathrm{kV}$ lines are available at the Samanalawewa Dam site for the plants $1 \& 2$ and the third plant could be connected to the $33 \mathrm{kV}$ line at Watawala by a $7 \mathrm{~km}$ long transmission line for connection to the national grid..

\section{Project Cost and The Benefits}

The Construction cost of the projects is estimated to be Rupees 550 Millions excluding the consultancy work. The average annual income from the planned project is expected to be Rs. 160 million.

\section{Environmental Concerns}

The project sites are completely uninhibited area and belongs to forest Department/ Ceylon Electricity Board. The project area is predominantly forestry and range land. Therefore, proposed project does not require relocation of people. Construction of Samanalawewa reservoir involved inundating of 897 ha. whereas the proposed power projects do not require inundating of land. 


\section{Conclusion}

As explained above, the preliminary study conducted shows that the proposed mini-hydro power project is technically, environmentally and economically feasible. Table 4 reveals that the annual energy benefit from the proposed minihydro power stations amounts to $11 \%$ of the average annual energy produced from the Samanalawewa Power Station in the recent past which has installed capacity of $120 \mathrm{MW}$. In other words, the hydro-power potential of Samanalawewa Project could be enhanced by $11 \%$.

The value of renewable energy from three plants could be estimated as Rs. 200 millions at the current average selling rate. The value of fuel imports for thermal power generation to cover up this energy would be in the range of Rs. 210 million to the country.

\section{Acknowledgements}

Author wishes to express his gratitude to Chief Engineer - Samanalawewa Power Station and General Manager - CEB for permitting to publish this paper on Samanalawewa Project.

\section{References}

1. CEB 1996-2004

Ceylon Electricity

Board(1996-2004) Monthly Monitoring

Reports of Samanalawewa Project

2. Harvey 1993

Adam Harvey, Micro-Hydro Design Manual A guide to small-scale water power scheme, Intermediate Technology Publications 1993.

3. Weerasinghe \& Somathilake $2001 \mathrm{M}$. Lakshitha Weerasinghe \& H.S. Somathilake Proposal to optimize the benefits of Samanalawewa waters. A paper presented for the Water Related Infrastructures Competition - 2000/2001 